Article

\title{
How Elite Politicization of Terror Impacts Sympathies for Partisans: Radical Right versus Social Democrats
}

\author{
Lars Erik Berntzen \\ Department of Comparative Politics, University of Bergen, 5007 Bergen, Norway; E-Mail: lars.berntzen@uib.no
}

Submitted: 15 February 2020 | Accepted: 4 June 2020 | Published: 17 July 2020

\begin{abstract}
The populist radical right is frequently engaged in intense political and normative conflict with their political opponents. Does this have a spillover effect on citizens' sympathies for populist radical right voters and the voters of their political antagonists, and if so, why? This is a study of citizens' affective evaluation of radical right and social democratic voters when exposed to intense conflict between the two parties at the elite level. It zooms in on the conflict between the Norwegian Progress Party and the Labour Party that revolves around the trauma of the 22 July 2011 terror attacks, in which a former Progress Party member committed two devastating attacks against the Labour government and Labour Youth summer camp. This is studied using a survey experimental approach, relying on panel data from the Norwegian Citizen Panel. Drawing on the authoritarian dynamics' literature, it incorporates the four-item child-rearing values index measure of authoritarian predispositions which offers a personality-based explanation for why people react differently to threat. In contrast to the authoritarian dynamics' literature, which has found that it is either authoritarians or non-authoritarians who react, this study finds that both authoritarians and non-authoritarians simultaneously respond to high-intensity political conflict. Whereas non-authoritarians rally in support of social democratic voters, authoritarians rally in support of radical right voters. Further differentiating between those with low and high authoritarianism scores, we see that lowauthoritarians also become more hostile to social democratic voters. This indicates that conflict involving populist radical right parties is a driver of personality-based, affective sorting of citizens. Since personality is relatively stable, the resulting state of polarization is also likely to be quite durable.
\end{abstract}

\section{Keywords}

authoritarianism; partisanship; political conflict; political polarization; populism; radical right; social democrats; terrorism

Issue

This article is part of the issue "Populism and Polarization: A Dual Threat to Europe's Liberal Democracies?" edited by Jonas Linde (University of Bergen, Norway), Marlene Mauk (GESIS - Leibniz Institute for the Social Sciences, Germany) and Heidi Schulze (GESIS-Leibniz Institute for the Social Sciences, Germany).

(C) 2020 by the author; licensee Cogitatio (Lisbon, Portugal). This article is licensed under a Creative Commons Attribution 4.0 International License (CC BY).

\section{Introduction}

We know that elite partisan polarization-where party elites from different parties grow increasingly ideologically distant from each other-impacts public opinion formation (Druckman, Peterson, \& Slothuus, 2013). Partisan conflict can at times escalate far past such disagreement over policy matters and become existential in nature. Beyond issues of ideological polarization, this study therefore examines what happens when conflict at the elite level becomes so emotionally charged that the opposing sides depict each other as a dangerous threat.
Does this also spill over onto the public's affective evaluation of the different partisan camps and impact on their sympathies and antipathies? If so, why?

These questions are investigated using a survey experimental approach, relying on panel data from the Norwegian Citizen Panel (NCP). It zooms in on the struggle between the social democratic Labour Party (Arbeiderpartiet, Ap) and their rivals from the populist radical right Progress Party (Fremskrittspartiet, FrP). The two parties have been locked in conflict since the Progress Party initially broke through in 1987, but the trauma of the July 22, 2011 terror attacks added fuel to 
the fire. On that summer day, the right-wing extremist Anders Behring Breivik carried out two consecutive attacks, killing 77 people, injuring hundreds more and laying part of the government complex in ruins.

The attacks were traumatic, not just because they were the first large-scale terrorist attacks in Norway, but also due to the perpetrator's background, ideological motivation, and whom he targeted. Breivik was a former member of the Progress Party and he attacked their main political antagonist, the Labour Party. Moreover, his attacks were ideologically motivated along the same line of thinking that the Progress Party and the broader anti-Islamic movement had espoused-that Labour were responsible for Muslim immigration and "sneak Islamization" of society (Berntzen \& Sandberg, 2014). While Labour initially responded by framing the terror as an attack on democracy itself rather than highlighting the terrorist's motivation to strike at them specifically, the attacks eventually began to bleed back into the ongoing partisan conflict between the Labour Party and Progress Party elites resulting in previously unseen levels of acrimony. In the experiments, respondents are exposed to perhaps the most intense exchange between the two parties over this trauma.

The authoritarian dynamics literature offers a plausible explanation as to precisely how and why such volatile elite conflicts might spill over depending on people's personality traits. Drawing on findings from that body of work, the overarching expectation is that people with authoritarian predispositions react differently to nonauthoritarians. Therefore, variations in authoritarian predispositions should account for differing affective impacts of exposure to this partisan struggle at the elite level. To test this, the study incorporates the four-item child-rearing values (CRV) index measure of authoritarian predispositions.

This assumption seems to hold. Overall, authoritarians do respond differently to the conflict than nonauthoritarians, but not in the straightforward manner originally theorized. Initially, the argument was that authoritarians are those who react to perceived threats (e.g., Stenner, 2005). In contrast, subsequent studies found that it was non-authoritarians who were reacting (e.g., Hetherington \& Suhay, 2011). I find that both nonauthoritarians and authoritarians react simultaneously to this elite level conflict and that their reaction patterns are opposite. Non-authoritarians rally around Labour voters, whereas authoritarians rally around Progress voters. Furthermore, low-authoritarians also react by becoming more hostile to Labour voters.

The remainder of the article is structured in the following manner: The subsequent section situates the study within the literature on polarization and authoritarian dynamics, followed by a section on the Norwegian case and conflict between the two political parties. This is followed by an overview of the data and research design, discussion of the results, and finally some concluding remarks.

\section{Dynamics of Partisanship}

In recent decades, radical right parties and movements have become a fixture of the political landscape in Western Europe (Ivarsflaten, 2008; Mudde, 2007; Weisskircher \& Berntzen, 2019). The radical right faction is fundamentally nativist and increasingly mobilizes on an anti-Muslim and anti-Islamic platform (Berntzen, 2019). Defining themselves as the voice of the people, their main political antagonists are the "elites"ranging from mainstream parties such as the social democrats to human rights organizations, journalists, and academics - whom they blame for fundamentally altering the characteristics of Western nations by letting them become Islamized.

A major concern is that the growth of such parties and movements is leading to an increased affective, partisan polarization of the citizenry (Mudde \& Rovira Kaltwasser, 2018), mirroring that which happened between Republicans and Democrats in the United States (see e.g., lyengar \& Westwood 2015, p. 691). Affective polarization is understood as an increasing distance between adherents of different identity-based groups, such as parties and ideological factions. It is composed of two dimensions: positive and negative partisanship. Positive partisanship refers to an attachment to ones' own identity-group (Campbell, Converse, Miller, \& Stokes, 1960 , p. 143), in the form of sympathizing with, loving, and trusting them. Reversely, negative partisanship refers to feeling antipathy, hatred, and distrust toward members of another identity-based group.

Increased affective partisanship could have deleterious effects on the functioning of democratic institutions, trust, and social cohesion. This scenario is made more volatile by the spate of terror attacks committed by militant Islamists (Nesser, 2018) and right-wing extremists (Ravndal, 2018) during the same period that the radical right have become major players in party politics. It has been established that elite partisan polarization impacts public opinion (Druckman et al., 2013). What happens when radical right politicians and their opponents engage in elite partisan conflict surrounding such traumatic events? Conflicts, where they politicize terror attacks by laying blame and signaling distrust and dislike of each other, could very well spill over onto citizens' affective evaluation of their voters.

Affective partisanship and polarization has been measured using a wide-ranging assortment of survey items, such as feeling thermometers (Lelkes \& Westwood, 2017, p. 489), trait stereotypes (Garrett et al., 2014; lyengar, Sood, \& Lelkes, 2012), trust (Levendusky, 2013), and social-distance measures gauging how comfortable people are in having close friends, neighbours, and having their children marry someone from the other party (Bogardus, 1947; lyengar et al., 2012; Knudsen, 2018; Levendusky \& Malhotra, 2016). Of these, the feeling thermometer is the most common measure (Lelkes \& Westwood, 2017, p. 489), where affective polariza- 
tion is computed as the difference between the score given to the party of the respondent and the score given to the opposing party (lyengar, Lelkes, Levendusky, Malhotra, \& Westwood, 2019) or their voters (Druckman \& Levendusky, 2019).

In instances where we wish to study the partisan impact of critical events and their politicization at the elite level, aggregate measures of polarization may render specific patterns of partisanship more obscure, particularly in the multi-party systems which characterize much of Western Europe. For this reason, looking at citizens' sympathies for the factions engaged in the conflict and their partisan supporters is more relevant.

Regardless of the context, the drivers of negative and positive affective evaluation of and by partisans are less well understood, although the social-psychological work on authoritarian dynamics offers a tantalizing answer. In this work, authoritarianism is defined as a personality trait, a pre-political need for conformity and resulting intolerance toward difference (Feldman \& Stenner, 1997; Hetherington \& Suhay, 2011; Stenner, 2005).

The work on authoritarian dynamics is informed by the broader literature on authoritarianism, but the insistence on understanding authoritarian dispositions as independent from other political orientations or attitudes sets them apart. The main critique levelled at the broader field is that they have constructed and utilized measures which conflate authoritarianism with conservatism and specific prejudices (e.g., Feldman \& Stenner, 1997; Hetherington \& Suhay, 2011), leading to the misidentification of authoritarianism as a uniquely right-wing phenomenon (Stenner, 2005; Stenner \& Haidt, 2018). Child-rearing items contrasting personal autonomy and social conformity have become the most favoured measure (e.g., Feldman \& Stenner, 1997; Hetherington \& Suhay, 2011; Stenner, 2005) which arguably allows us to escape the tautological reasoning that has otherwise plagued the authoritarianism literature (Hetherington \& Suhay, 2011, p. 550). The literature on authoritarian dynamics is also unified by their emphasis on threat as a key interaction term which allows us to explain many changes in attitudes and behaviour when combined with authoritarianism.

While united in these respects, the authoritarian dynamics field can be roughly divided into two camps, based on two disputes: First, is authoritarianism a latent trait that only becomes activated under certain circumstances, or is it a consistent disposition? Second, who is it that reacts to environmental stimuli in the form of threats-authoritarians or non-authoritarians?

The first camp, epitomized by the pioneering work of Stenner and Feldman, understand peoples' authoritarian dispositions as latent (e.g., Feldman, 2003; Feldman \& Stenner, 1997; Stenner, 2005; Stenner \& Haidt, 2018). That is, such dispositions have little to no bearing on their political views, attitudes, and choices until they are exposed to threatening messages. Stenner and Feldman argue that people with authoritarian dispositions are par- ticularly susceptible to normative threats: Messages that instil a sense of perceived threat to the unity and uniformity of society. In this account, it is those with intermediate to high authoritarianism scores who become activated under situations of threat. Several studies building on the authoritarian dynamics theory have found similar results. While some studies find that threats increase prejudice and intolerance across the board, it does so especially for those with marked authoritarian dispositions (e.g., Lavine, Lodge, Polichak, \& Taber, 2002; Merolla \& Zechmeister, 2009). Threats have, therefore, been described as having a galvanizing effect on authoritarians (Sniderman, Hagendoorn, \& Prior, 2004).

In contrast, the other camp, most clearly embodied by the work of Hetherington and colleagues (e.g., Hetherington \& Suhay, 2011) argue that people with high levels of authoritarianism have relatively stable preferences when it comes to illiberal policies. This is taken as an indication that their dispositions are not latent but consistently and "chronically" activated (Hetherington \& Suhay, 2011, p. 548). Instead of it being the highly authoritarian individuals who react to threat, they argue that threat exposure most clearly impacts those with no or lower levels of authoritarianism. It is this segment of the population that alter their preferences, thereby becoming more similar to the authoritarians. In other words, the non-authoritarians "catch up" with the authoritarians in what has been described as a mobilizing effect (Claassen \& McLaren, 2019; Hetherington \& Suhay, 2011; Hetherington \& Weiler, 2009; Vasilopoulos, Marcus, \& Foucault, 2018). Rather than utilizing normative threat, they contend that physical threat of terror provides a better gauge as it 'plausibly threatens those across the authoritarianism distribution' (Hetherington \& Suhay, 2011, p. 549).

These two positions and the findings that underpin them have been presented as mutually exclusive (e.g., Claassen \& McLaren, 2019). While the disagreement continues about whether or not those with high levels of authoritarianism are always activated (Feldman, 2020), more recent acknowledgement that non-authoritarians may respond when they believe the actions of some people can 'significantly reduce their freedom of or be a direct threat to their lives' (Feldman, 2020, p. 42), suggests that the two positions are not completely at odds. In other words, while authoritarians react when they perceive a challenge to traditional norms and values, nonauthoritarians are most concerned with threats to personal and civil freedoms.

Therefore, the specific threats people are exposed to seem to produce different outcomes. Previous studies have found that one of the two groups react-either the authoritarians galvanize, or the non-authoritarians mobilize. It is important to note that none of these studies have zoomed in on specific partisan conflicts, but often look at more overarching issues such as opposition to immigration (e.g., Claassen \& McLaren, 2019; Sniderman et al., 2004), support for increased security and surveil- 
lance measures (e.g., Vasilopoulos et al., 2018), as well as support for specific political parties (e.g., Vasilopoulos $\&$ Lachat, 2018). When it comes to affective political conflict at the elite level, however, it is plausible that nonauthoritarians rally in response to one party, whilst authoritarians rally in response to another.

\section{The Terror Attacks and Political Conflict between the Radical Right and Social Democrats}

The most prominent conflict that the radical right Progress Party is engaged in is with the social democratic Labour Party. This conflict has simmered ever since the Progress Party had their first electoral breakthrough in 1987 and has primarily revolved around issues of Muslim immigration and national security. The conflict escalated after the 22 July 2011 terror attacks, when the right-wing extremist Anders Behring Breivik killed 77 people in two terrorist attacks directed at the government quarters and Labour Youth camp (see e.g., Berntzen \& Sandberg, 2014). Breivik obsessed over the supposed "sneak Islamization" of Norway for which he primarily blamed the Labour Party. The term "sneak Islamization" was initially introduced to Norwegian political discourse by Progress Party leader Siv Jensen during the parliamentary election campaign 2009-in which she too blamed the Labor Party for this supposed development (Jupskås, 2015, p. 68).

Not long before the attacks, the Progress Party had campaigned on the issue of Norway becoming Islamized by stealth, the very same issue that Breivik claimed motivated his attacks against the Labour government and party (Berntzen \& Sandberg, 2014). Despite this, the primary political reaction in the immediate aftermath was one of unity and depoliticization of the attacks by deemphasizing the fact that the terrorist deliberately targeted the Labour government and the Labour Youth camp (Lödén, 2014). Instead, the then Prime Minister, Jens Stoltenberg of the Labour Party, described it as an 'attack on us all,' promising that the response would only be 'even more democracy' (Stoltenberg, 2011). Additionally, Stoltenberg made a public appeal to 'tone down antiimmigrant rhetoric' and to 'avoid assigning blame to a particular political party' (Wiggen, 2012)-meaning the Progress Party. While stating that the party accepted no responsibility for the heinous crimes committed by Breivik,' Progress Party leader Siv Jensen also proclaimed that they would stop using the same rhetoric as they had before (Wiggen, 2012). In other words, both the terror attack and issues of immigration and any supposed "sneak Islamization" were off the table-for a time.

In the local elections held not long after, the Labour Party surged while the Progress Party suffered a setback. The Progress Party's loss of support was in large part because immigration, their most important issue, had not been discussed (Bergh \& Bjørklund, 2013). During the national elections in 2013, the Progress Party also suffered a substantial electoral setback, but nevertheless managed to enter government for the first time. They formed a minority coalition government with the Conservative Party (Høyre, $\mathrm{H}$ ) by securing parliamentary backing from the Christian Democrats (Kristelig Folkeparti, KrF) and the Liberals (Venstre, V), thereby replacing the previous Labour-led government. The Progress Party and Conservatives secured a second term in government after the 2017 national elections, initially with continued parliamentary backing from the Christian Democrats and Liberals. This was followed by the Liberals and subsequently the Christian Democrats officially entering the government coalition as of January 2018 and January 2019, respectively.

As the years passed the initial depoliticization of the terror attacks met resistance from factions within the Labour Party. Meanwhile, the parliamentary wing of the Progress Party gradually returned to form and became more strident in their anti-immigrant and anti-Muslim messaging (Jupskås, 2016, p. 179). This closely coincided with the rise of a faction within the Labour Party who wanted to hold the Progress Party responsible. It infused a new level of acrimony and vitriol into the conflict between the two factions. An early portent of the future hostilities came during the transition period after the national elections in 2013 and just before the Labour-led government tendered its resignation when Prime Minister Stoltenberg asked Progress Party leader Siv Jensen to apologize for using the term "sneak Islamization" - a request she promptly refused (Johnsen \& Hvidsten, 2013).

The conflict reached its peak after Minister of Justice Sylvi Listhaug from the Progress Party shared a post on Facebook, March 9, 2018, writing that 'the Labor Party believes that the rights of terrorists are more important than the nation's security. LIKE AND SHARE!' accompanied by a picture of an Islamic State-soldier wielding a knife (Svaar, 2018). Labour party leader Jonas Gahr Støre retorted by saying that Sylvi Listhaug from the Progress Party 'deliberately, calculatedly, kindles the hatred that took so many lives on 22 July' (Sørsdahl, 2018).

Listhaug was subsequently forced to resign as Minister of Justice on March 20, 2018 but maintained her prominent position within the ranks of the Progress Party and was officially elected as 1st Deputy Leader on May 5, 2019 (Gilbrant \& Suvatne, 2019). In a sign of renewed confidence by the coalition government, Listhaug was also appointed as Minister of Health and Care services, May 3, 2019.

The Progress Party withdrew from the coalition government on January 20,2020, after having sat in government for six years, two months and twenty days. They chose to withdraw after the government extracted a female Islamic State member and her children from an internment camp in Syria (Jensen, 2020). The Conservative Prime Minister Erna Solberg had initially opposed retrieving female Islamic State members and their children with Norwegian citizenship, whereas the government coalition partners the Christian Democrats and Liberals and several opposition parties including Labour had gone out 
in favour of 'bringing them home' (Johnsen, 2019). For the Progress Party, the issue of extracting these women and their children was directly related to the heated conflict between then Minister of Justice Listhaug and Labour leader Gahr Støre. Listhaug herself argued the conflict which played out in March 2018 was based on a misrepresentation of her desire to enact a law withdrawing Norwegian citizenship from Islamic State fighters (Sylvi Listhaug forsvarer, 2018).

\section{Data and Research Design}

Data for the study $(N=1370)$ were collected from a probability-based online national survey conducted by the NCP between May 21 and June 10, 2019. See the NCP methodology report for details (Skjervheim, Høgest $\varnothing l$, Bjørnebekk, \& Eikrem, 2019). The data is available free of cost for scholars via the Norwegian Social Science Data Archive. The study includes measures for authoritarian pre-dispositions, experimental exposure to political conflict, and party voter likeability for Labour and Progress Party voters.

The main hypothesis of this study is that the effect of exposure to the 22 July-related political conflict between radical right Progress Party and the social democratic Labour Party on citizens' sympathies toward these two parties' voters vary according to peoples' authoritarian predispositions. To test this, I have chosen a betweensubjects experimental design. The experimental design consists of exposure to statements by the then Minister of Justice, Sylvi Listhaug (Progress Party) and party leader Jonas Gahr Støre (Labour Party) in the form of vignettes. Whereas the Progress Party message describes Labour as a challenge to traditional norms and values by placing the rights of (Muslim) terrorists above national security, the Labour message is that the Progress Party induces right-wing extremism which poses a threat to peoples' personal safety and liberty. In the case of the Progress Party message, the physical threat of terror is present but more implicit. Respondents were randomly allocated to one of two treatments or control (no treatment), and subsequently asked to rate how much they like or dislike Labour and Progress Party voters, respectively, on a seven-point sympathy barometer scale established as standard in the NCP, ranging from "intensely dislike" (1) to "intensely like" (7).

Note that respondents were explicitly asked about their view of party voters and not the party itself. Sympathy measures that only use the party label in their question wording (for instance asking about "Republicans" and "Democrats" in the US) have been found to measure affect for party elites and not the masses (Druckman \& Levendusky, 2019). The Like-Dislike sympathy barometer is itself an established measure to gauge affect and polarization (see e.g., Gidron, Adams, \& Horne, 2019; Hansen \& Kosiara-Pedersen, 2017; Lauka, McCoy, \& Firat, 2018) and is an attempt to get at the same phenomenon as the more traditional feeling ther- mometer's answer scale that ranges between 0 and 100 . The degree to which these are functionally equivalent or whether one is superior to the other has not yet been established.

The full wording of the survey experiments exposing respondents to the 22 July-related political conflict between the Progress Party and Labour Party were as follows:

\section{Progress Party message}

Please read the text below carefully. Norway has experienced various political conflicts in recent times. Whilst involved in one of these conflicts, Sylvi Listhaug from the Progress Party wrote that 'the Labour Party believes that the rights of terrorists are more important than the nation's security. LIKE AND SHARE!.'

\section{Labour Party message}

Please read the text below carefully. Norway has experienced various political conflicts in recent times. Whilst involved in one of these conflicts, Jonas Gahr Støre from the Labour Party said that Sylvi Listhaug from the Progress Party 'deliberately, calculatedly, kindles the hatred that took so many lives on the $22 \mathrm{nd}$ of July.'

Previous work on authoritarianism where threats are manipulated in an experimental setting (e.g., Lavine, Lodge, \& Freitas, 2005; Merolla \& Zechmeister, 2009; Stenner, 2005) have been criticized on (at least) two counts. First, because they are only able to activate a threat response from those at one end of the authoritarianism scale but not the other (Hetherington \& Suhay, 2011, p. 551). Second, because the relationship between the exogenous threats created by the experimenter and real-world threats often remain unclear due to the fictitious nature of the experiment (Hetherington \& Suhay, 2011, p. 551), with there sometimes being a vague operationalization of threat or at other times more outlandish scenarios.

My experimental conditions address both points of criticism. First, the treatments are direct replications of a heated real conflict on a word for word basis. While a full year passed between the intense episode and its utilization in the survey, no other episodes arose in the interim to eclipse it nor did the two parties make any significant attempts at reconciliation. This has its own potential drawbacks but provides some assurance that the messages will be perceived as threatening. Second, both relate to the threat of terrorism, either by rightwing extremists or Islamist extremists. In addition, both messages single out their political opponents as the underlying cause of this threat. They thereby cover both dimensions-physical and normative threat-that have been stressed by both sides in the academic debate.

The measure for authoritarianism used in the analysis is constructed from four questions that contrast pairs of CRV in terms of personal autonomy versus social con- 
formity. Respondents were asked to choose which is more important to them: independence or respect for parents; obedience or self-reliance; being considerate or well-behaved; and curiosity or good manners. Each question was coded so that the authoritarian option was equal to 1 and the non-authoritarian option was 0 . A scale was created by averaging across the four questions. The scale was then collapsed, where choosing 3 to 4 of the authoritarian options is classified as highauthoritarian, 2 as low-authoritarian, and 0 to 1 as nonauthoritarian (see Figure 1). The authoritarianism measure is crucial to discern whether, and why, exposure to partisan conflict at the elite level may have different effects on citizens' affective evaluation of voters.

My choice of collapsing the authoritarianism scale into three categories deviates from the more prevalent approaches of treating it either as a continuous or dichotomous variable. At the same time, the resulting analyses are consistently discussed using a similar tripartite distinction (e.g., Hetherington \& Suhay, 2011, p. 553; Stenner \& Haidt, 2018, p. 192). This indicates that there are meaningful qualitative differences between people with low, intermediate, and high scores that have implications for when and why someone's predispositions become activated. Considering this, treating authoritarianism as a categorical and not a continuous or simply dichotomous variable allows for a more straightforward reading of the potentially differentiated interaction effects between varying levels of authoritarianism and the two experimental treatments (threat messages).

\section{Results}

During the last decade, there has been an ongoing debate about the proper use, interpretation, and presentation of statistical inference. In my analysis, I try to steer clear of the standard pitfalls, such as using $p<0.05$ as a clear line distinguishing between significance and non-significance (Wasserstein \& Lazar, 2016). Instead,
I embrace the ATOM principle-"Accept uncertainty. Be thoughtful, open, and modest" (Wasserstein, Schirm, \& Lazar, 2019, p. 2). To do so, I differentiate between substantive and statistical significance while enumerating all results for transparency-providing effect sizes, standard deviations and significance values reported as continuous quantities. For p-values, I refer to Hug's (2019) designations ranging from decisive evidence for $\mathrm{p}$-values ranging between $0.000-0.001$, very strong for $p<0.001-0.004$, strong for $p<0.004-0.012$, substantial for $p<0.012-0.037$, moderate for $p<0.037-0.132$ and weak for $p<0.132-1.000$.

I begin by looking at the aggregate effects on citizens' sympathies for Progress and Labour Party voters (see Figure 2). Here we see that exposure to the elite conflict does not substantively shift citizens' sympathies for radical right Progress Party voters, nor Labour Party voters. Concerning the affect for Labour voters, the effect of the Labour message is substantively negligible to nonexistent $(b=0.039, S D=0.082, p=0.587)$. The same holds when it comes to the impact of the Progress message $(b=0.044, S D=0.081, p=0.632)$. For citizens' sympathies for Progress voters, we see that the Labour message may exert a very small substantive effect in favour of Progress voters ( $b=0.134, S D=0.097, p=0.169)$, but the weak $p$-value makes any clear conclusions untenable. The Progress message has no discernible effect ( $b=0.021, S D=0.099, p=0.829$ ).

Having established that the elite conflict between the Progress Party and Labour has no notable effects on sympathies toward the respective parties' voters when looking at the population in aggregate, I now turn to citizens' sympathies sorted by their authoritarian predispositions. Authoritarianism is here treated as a categorical variable, ranging from non-authoritarian to lowauthoritarian and finally high-authoritarian.

The main expectation was that citizens' response to exposure to elite conflict between the radical right Progress Party and social democratic Labour Party should

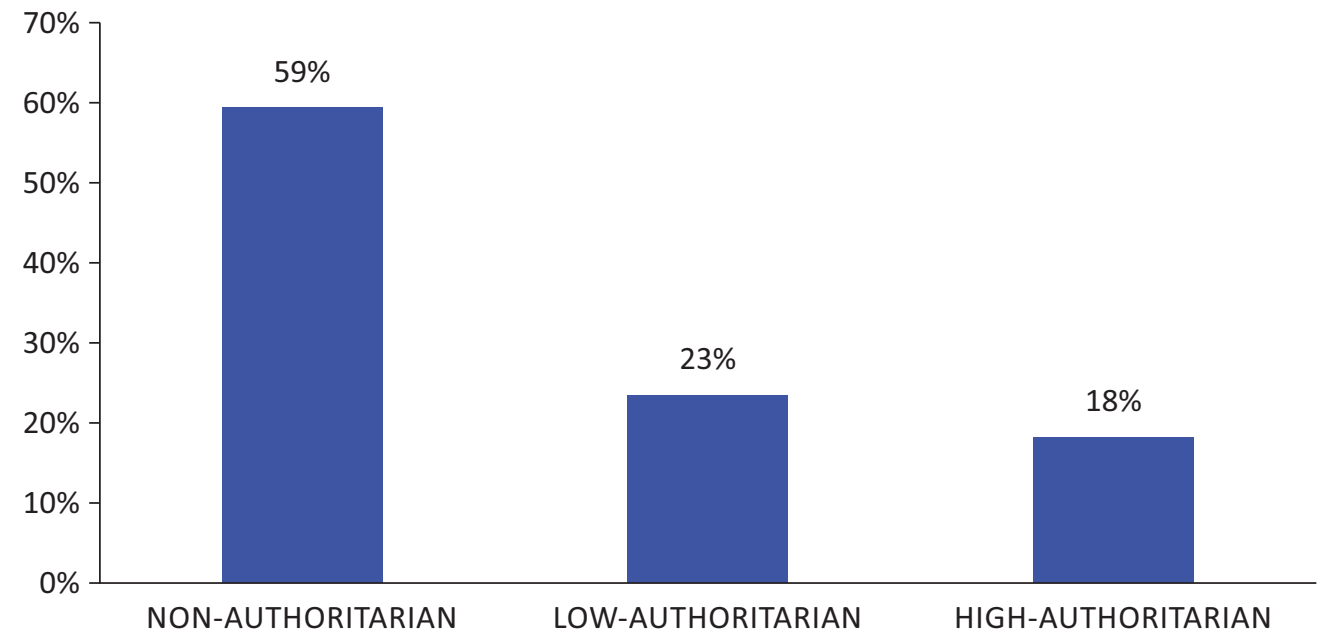

Figure 1. Distribution of authoritarian pre-dispositions. Notes: NCP, wave $15 . \mathrm{N}=1370$. Bars reflect \% of the population falling into each category. 


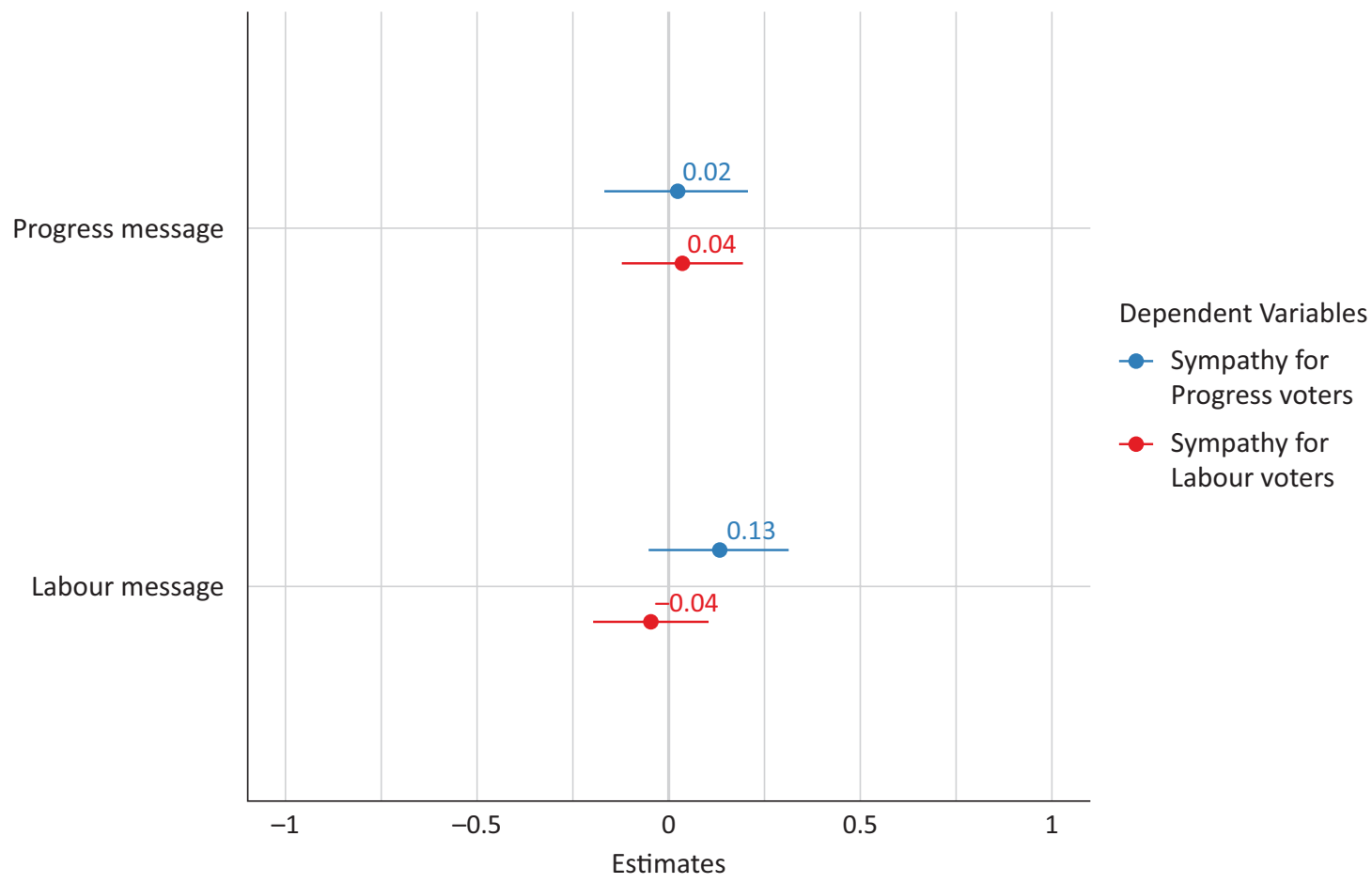

Figure 2. No aggregate effect of exposure to elite conflict between Progress Party and Labour Party on citizens' sympathies for their voters. Notes: NCP, wave $15 . \mathrm{N}=1340 .{ }^{*} p<0.1{ }^{* *} p<0.05 * * * p<0.01$.

vary depending on their levels of authoritarian predispositions. The formula below summarizes the OLS procedure for identifying the affective evaluation of Labour and Progress voters, respectively:

Sympathy for party voters =

$=\alpha+\beta 1$ (Low authoritarianism)

$+\beta 2$ (High authoritarianism)

$+\beta 3$ (Labour message) $+\beta 4$ (Progress message)

$+\beta 5$ (Low authoritarianism $\times$ Labour message)

$+\beta 6$ (High authoritarianism $\times$ Labour message $)$

$+\beta 7$ (Low authoritarianism $\times$ Progress message)

$+\beta 8$ (High authoritarianism $\times$ Progress message $)+\varepsilon$

I now turn to look at sympathy for Labour Party voters (see Figure 3). Non-authoritarians become slightly more sympathetic toward Labour Party voters when exposed to both the Labour message $(b=0.204, S D=0.117$, $p=0.083)$ and the Progress message $(b=0.28$, $S D=0.119, p=0.021)$. In other words, the conflict seems to have a rallying effect on non-authoritarians in favor of Labour. For low-authoritarians, the directionality is reversed for both exposure to the Labour message $(b=-0.49, S D=0.221, p=0.026)$ and the Progress message $(b=-0.384, S D=0.221, p=0.084)$. Substantively, the effects of exposure to the Labour message are relatively strong, making low-authoritarians more unsympathetic toward Labour voters. For high-authoritarians, exposure to the political conflict has no discernible impact on their sympathies for Labour voters, neither in the case of the Labour message $(b=0.13, S D=0.243, p=0.594$ ) nor the Progress message $(b=-0.30, S D=0.224$, $p=0.223$ ).

Let us now look at citizens' sympathies for Progress Party voters, beginning with non-authoritarian citizens (see Figure 4). The Progress message has substantively small, but discernible impact $(b=-0.230, S D=0.142$, $p=0.105)$, indicating that it makes non-authoritarians somewhat more unsympathetic toward Progress voters. In contrast, the Labour message condemning the Progress Party has no noticeable effect $(b=-0.139$, $S D=0.140, p=0.322$ ). For low-authoritarians, the Labour message has a, substantively speaking, moderate rallying effect on their sympathies for Progress voters $(b=0.478, S D=0.263, p=0.070)$. The same is not the case for the Progress message $(b=0.307, S D=0.265$, $p=0.247)$. Finally, for the high-authoritarians we see that whilst the Labour message has no discernible effect $(b=0.352, S D=0.289, p=0.224)$, the Progress message has a noticeable substantive rallying effect on their sympathies for Progress voters $(b=0.758, S D=0.292$, $p=0.010)$. That is, highly authoritarian individuals become more positive toward Progress voters.

The main expectation was that citizens' response to exposure to elite conflict between the radical right Progress Party and the social democratic Labour Party should vary depending on their levels of authoritarian predispositions. This is borne out; authoritarians do, by and large, respond differently to the conflict than nonauthoritarians. Overall, low-authoritarians are the most susceptible to the conflict. Both Labour and Progress messages have a counter-mobilizational effect, decreasing their sympathy for Labour voters, whereas the Labour 


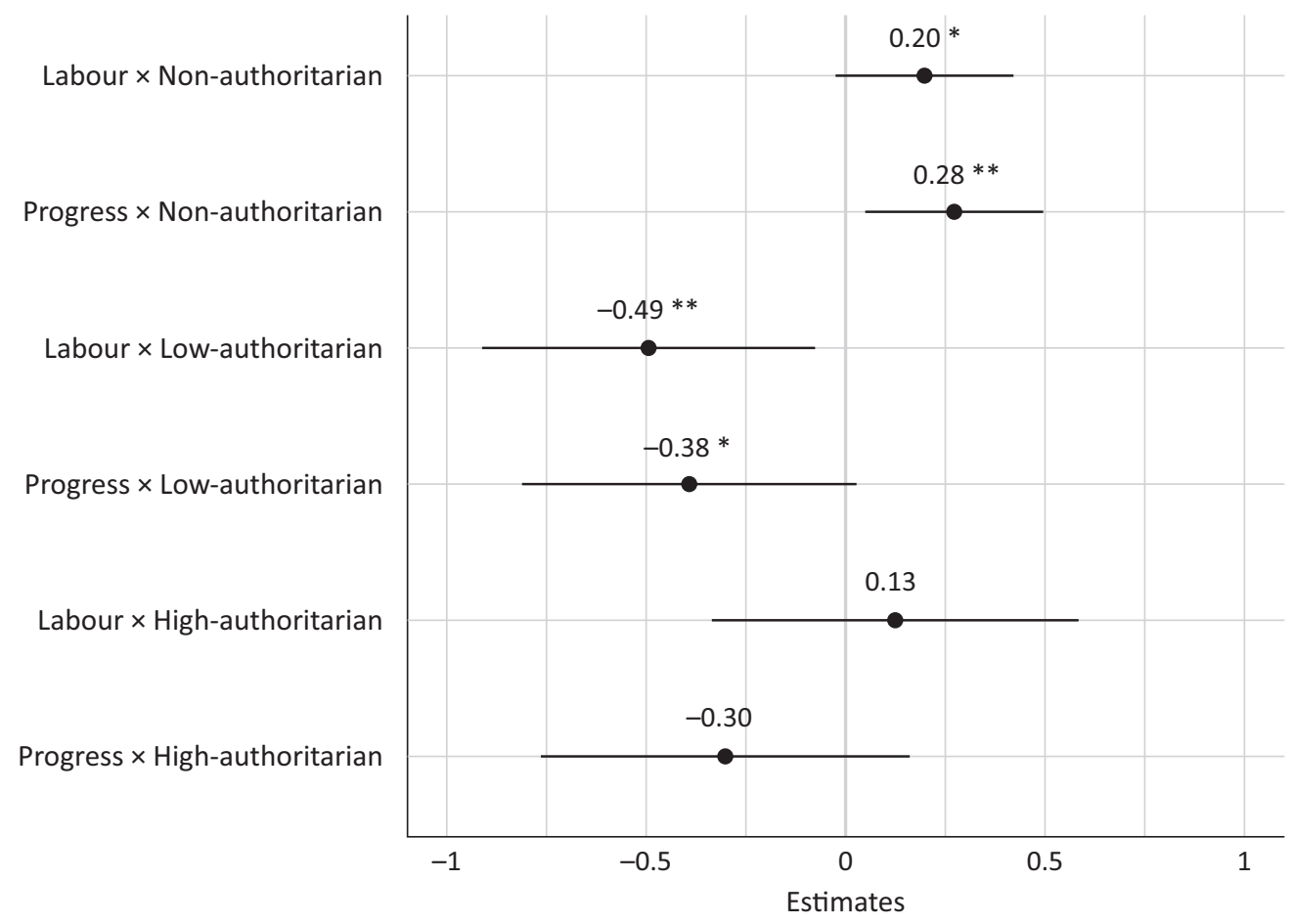

Figure 3. Exposure to elite conflict rallies non-authoritarians for and mobilizes low-authoritarians against Labour party voters, with no discernible impact on high-authoritarians. NCP, wave 15. $\mathrm{N}=1045 .{ }^{*} p<0.1{ }^{* *} p<0.05^{* * *} p<0.01$.

(but not the Progress message) has a rallying effect in favour of Progress voters. Substantively, the effect sizes are intermediate. In contrast, we see that exposure does not alter the affective evaluation of Labour voters by highauthoritarians, but when exposed to the Progress message they become markedly more sympathetic toward
Progress voters. In comparison, non-authoritarians become somewhat more sympathetic toward Labour voters when exposed to the conflict. Concerning their sympathies for Progress voters, the Labour message has no impact while the Progress message seems to make them slightly less sympathetic. See Table 1 for a full overview.

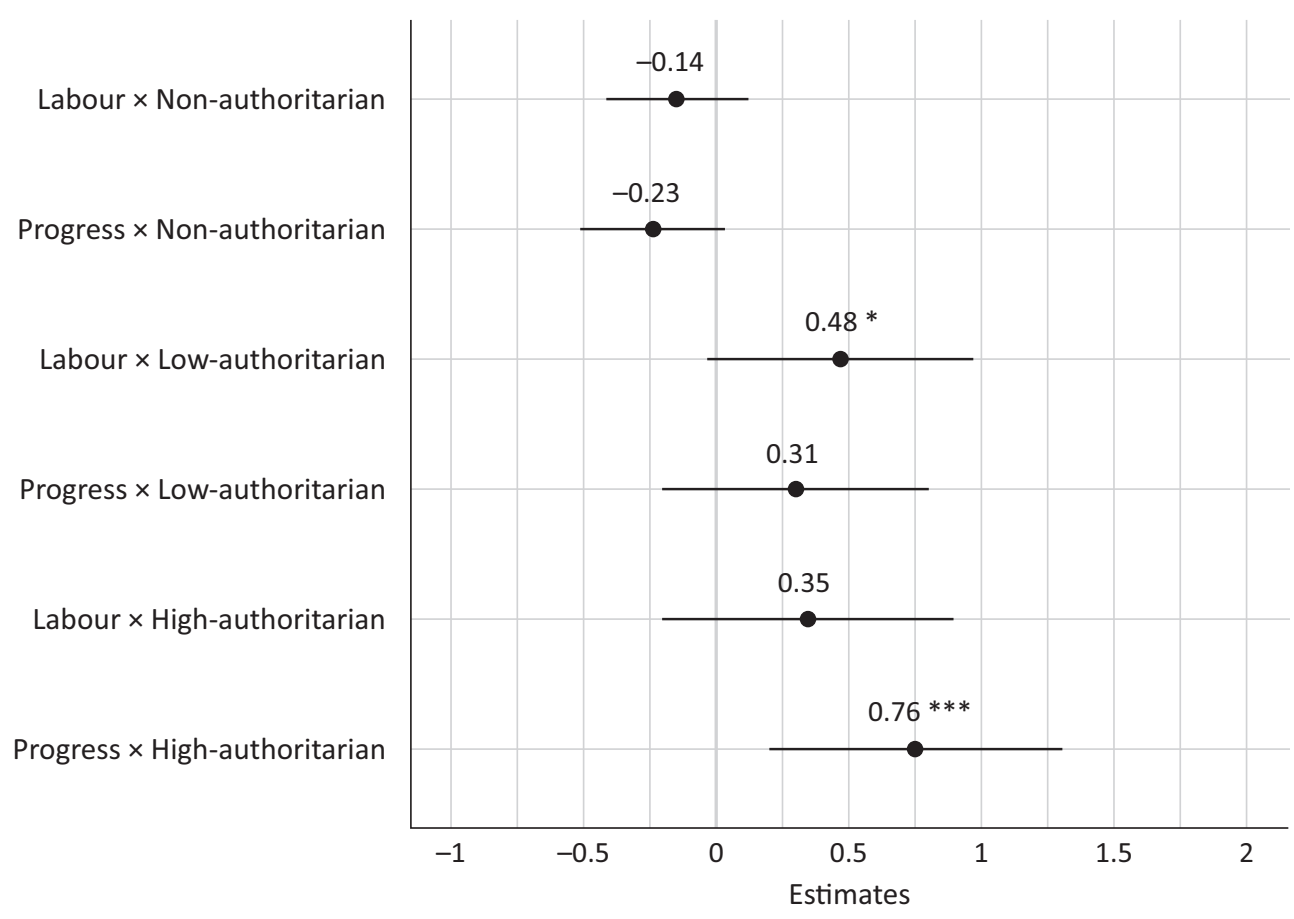

Figure 4. Exposure to elite conflict between Labour and Progress party mobilizes non-authoritarians against and rallies lowand high-authoritarians for Progress party voters. NCP, wave 15. $\mathrm{N}=1046 .{ }^{*} p<0.1 * * p<0.05^{* * *} p<0.01$. 
Table 1. Citizens' sympathy for Labour and Progress Party voters (OLS)

\begin{tabular}{|c|c|c|c|c|c|c|c|c|c|c|c|c|}
\hline \multirow[b]{2}{*}{ Predictors } & \multicolumn{3}{|c|}{ Labour voters (1) } & \multicolumn{3}{|c|}{ Progress voters (1) } & \multicolumn{3}{|c|}{ Labour voters (2) } & \multicolumn{3}{|c|}{ Progress voters ( 2 ) } \\
\hline & Estimates & $\mathrm{Cl}$ & $P$ & Estimates & $\mathrm{Cl}$ & $P$ & Estimates & $\mathrm{Cl}$ & $P$ & Estimates & $\mathrm{Cl}$ & $P$ \\
\hline (Intercept) & $4.32 * * *$ & $4.21-4.43$ & $<0.001$ & $3.14 * * *$ & $3.01-3.28$ & $<0.001$ & $4.35 * * *$ & $4.19-4.51$ & $<0.001$ & $3.01 * * *$ & $2.81-3.20$ & $<0.001$ \\
\hline Labour message & -0.04 & $-0.20-0.12$ & 0.587 & 0.13 & $-0.06-0.33$ & 0.169 & $0.20 *$ & $-0.03-0.43$ & 0.083 & -0.14 & $-0.42-0.14$ & 0.322 \\
\hline Progress message & 0.04 & $-0.12-0.20$ & 0.632 & 0.02 & $-0.17-0.22$ & 0.829 & $0.28 * *$ & $0.04-0.51$ & 0.021 & -0.23 & $-0.51-0.05$ & 0.105 \\
\hline Low authoritarianism & & & & & & & 0.04 & $-0.25-0.34$ & 0.795 & 0.21 & $-0.15-0.57$ & 0.255 \\
\hline High authoritarianism & & & & & & & $-0.48 * * *$ & $-0.81-0.15$ & 0.004 & $0.41 * *$ & $0.02-0.80$ & 0.040 \\
\hline Labour msg $\times$ Low auth & & & & & & & $-0.49 * *$ & $-0.93-0.06$ & 0.026 & $0.48 *$ & $-0.04-1.00$ & 0.070 \\
\hline Progress msg $\times$ Low auth & & & & & & & $-0.38 *$ & $-0.82-0.05$ & 0.084 & 0.31 & $-0.21-0.83$ & 0.247 \\
\hline Labour msg $\times$ High auth & & & & & & & 0.13 & $-0.35-0.61$ & 0.594 & 0.35 & $-0.22-0.92$ & 0.224 \\
\hline Progress msg $\times$ High auth & & & & & & & -0.30 & $-0.78-0.18$ & 0.223 & $0.76 * * *$ & $0.18-1.33$ & 0.010 \\
\hline Observations & & 1340 & & & 1341 & & & 1045 & & & 1046 & \\
\hline $\mathrm{R}^{2} / \mathrm{R}^{2}$ adjusted & & $0.001 /-0.001$ & & & $0.002 / 0.000$ & & & $0.039 / 0.032$ & & & $0.053 / 0.045$ & \\
\hline
\end{tabular}

Notes: ${ }^{*} p<0.1^{* *} p<0.05^{* * *} p<0.01$. 


\section{Conclusion}

This is the first study of how affective polarization and terror-related conflict at the elite level impacts citizens' sympathy toward voters. It helps piece together precisely how threats may alter peoples' attitudes and preferences. It has done so by utilizing a concrete, real-world conflict and messages that are likely to be perceived as threatening in one way or another to large segments of the population. The study shows that terror-related conflict between the radical right and social democrats has a spill-over effect on citizens' sympathies for their voters.

The conflict affects citizens' according to their existing authoritarian predispositions. Non-authoritarians react by rallying around social democratic partisans, whilst low- and high-authoritarians rally around radical right partisans. The findings, therefore, speak directly to the ongoing debate within the authoritarianism field, providing support for a modified version of what has been labelled the authoritarian dynamics' theory. Initially, the argument was that people with authoritarian personality traits would react to exposure to threats (e.g., Feldman \& Stenner, 1997; Stenner, 2005). Later findings instead indicated that non-authoritarians were the ones who reacted strongly to threats. Some have posited these as competing explanations (e.g., Claassen \& McLaren, 2019; Hetherington \& Suhay, 2011). In my study, however, it becomes clear that both non-authoritarians and authoritarians can react simultaneously when exposed to highintensity, partisan conflict at the elite level.

As to the dispute over whether authoritarians are "chronically" activated (Hetherington \& Suhay, 2011) or only become activated under specific circumstances (Feldman \& Stenner, 1997; Stenner, 2005), my findings provide some support for the latter position. The academic disagreement on this count may simply reflect the nature of the given scenarios investigated. For one, they have frequently looked at or experimentally utilized differing threats. Furthermore, they have not looked at episodes of actual partisan conflict. My findings demonstrate that both authoritarians and nonauthoritarians can become simultaneously "activated" by political conflict within the same polity. Strictly speaking, this is therefore not just an authoritarian dynamic in the sense originally implied by Feldman, Stenner and others (e.g., Feldman \& Stenner, 1997), where only authoritarians react.

Now, why exactly is it that we see these different response patterns? While both messages contain a physical and normative threat element, the Labour Party message is more in line with what the literature indicates that non-authoritarians react to while the Progress Party message is more in line with what authoritarians react to. Yet, while this episode is among the most intense, it is not the first instance of conflict between the two parties along these normative lines. The response patterns are relatively uniform, with non-authoritarians becoming more sympathetic to Labour voters when exposed both to the Labour and the Progress message, indicating that their response is at least partially conditioned by the considerable length of time they have been exposed to the conflict between the radical right and their social democratic antagonists over the years. For instance, the Progress Party has consistently painted the Labour Party as a threat to the unity and cohesion of "traditional" Norwegian society through Muslim immigration and "sneak Islamization," whereas the Labour Party depicts the Progress Party as a threat to decency, political stability, and minority rights.

Owing to the nature of the experiments utilized in this study, it is difficult to truly disentangle whether these variations are due to the messages, the actors, or a combination of the two. Just as with this case, realworld conflicts often involve different themes and threat scenarios pushed by specific political actors. To build on the findings presented in this paper, a next step would be to design new experiments with hypothetical scenarios varying all the elements above. Another related aspect to investigate further is the more complex, longitudinal interaction-effects between direct party identification and authoritarianism within multi-party systems.

To reiterate, the key findings were that 1 ) both nonauthoritarians and authoritarians (low to high) can react simultaneously to threats, and that 2) in the case of partisan conflict their reaction patterns may be diametrically opposite. While the terror attacks themselves and the subsequent conflict is specific to the Norwegian case, it is in my estimation very plausible that these findings are generalizable to other cases within the sphere of liberal democracies in Western Europe and elsewhere. The socio-political specificity of these cases, however, such as processes of partisan sorting over a long period and the comparative primacy of party-political identity over ethnicity and other identities (see e.g., Westwood et al., 2018), makes it less likely that the findings can be readily generalized to non-WEIRD populations (Western, educated, rich and democratic).

In any case, within the sphere of liberal democracies, the results indicate that a continued conflict at the elite level between the radical right and their social democratic adversaries may contribute to a growing affective, partisan divide among citizens based on their authoritarian pre-dispositions in terms of whom they sympathize with. Beyond the overarching similarities in culture and political development, this position is premised on the finding that personality is relatively stable over time (e.g., Stenner, 2005, on authoritarianism; for stability of broader personality traits, see e.g., Damian, Spengler, Sutu, \& Roberts, 2019; Hampson \& Goldberg, 2006). Non-authoritarians could drift closer to the "mainstream," pro-social democratic camp and the low- to high-authoritarians in the "populist," proradical right camp. If the pattern of conflict is maintained, it could cause a relatively even affective split of the population, as non-authoritarians make up around half the population and the combined tally of low- to 
high-authoritarians the other half. The impact on negative affect is less clear-cut, but here we could also see an increasing gap as low-authoritarians move further away from the non-authoritarians and closer to the high-authoritarian baseline. The result may well be that the neutral ground-holding neither sympathies nor antipathies for either party camp-is whittled away. This would be in line with but not as far-ranging as the scenario Mudde and Rovira Kaltwasser discuss, wherein politics is completely bifurcated into a struggle between "liberal democracy" and "populism" (Mudde \& Rovira Kaltwasser 2018, p. 1685).

\section{Acknowledgments}

Many thanks to Raimondas Ibenskas, Manès Weisskircher, Linn A. C. Sandberg, the anonymous reviewers and the editors of this thematic issue, whose comments helped improve this article. I am also grateful for comments to a previous version of this paper received during a panel at the American Political Science Association Annual Meeting in Washington, D.C, August 2019.

\section{Conflict of Interests}

The author declares no conflict of interests.

\section{References}

Bergh, J., \& Bjørklund, T. (2013). Lokalvalget i skyggen av 22. Juli [The local elections in the shadow of July 22]. In J. Bergh \& D. A. Christensen (Eds.), Et robust lokaldemokrati [A robust local democracy] (pp. 21-43). Oslo: Abstrakt forlag.

Berntzen, L. E. (2019). Liberal roots of far right activism: The Anti-Islamic movement in the 21st Century. London: Routledge.

Berntzen, L. E., \& Sandberg, S. (2014). The collective nature of lone wolf terrorism: Anders Behring Breivik and the anti-Islamic social movement. Terrorism and Political Violence, 26(5), 759-779.

Bogardus, E. S. (1947). Measurement of personal-group relations. Sociometry, 10(4), 306-311.

Campbell, A., Converse, P. E., Miller, W. E., \& Stokes, D. E. (Eds.). (1960). The American voter. Chicago, IL: University of Chicago Press.

Claassen, C., \& McLaren, L. (2019). Do threats galvanize authoritarians or mobilize non-authoritarians? Experimental tests from 19 European societies. Social Science Research Network. http://dx.doi.org/10.2139/ ssrn. 3278685

Damian, R. I., Spengler, M., Sutu, A., \& Roberts, B. W. (2019). Sixteen going on sixty-six: A longitudinal study of personality stability and change across 50 years. Journal of Personality and Social Psychology, 117(3), 674-695.

Druckman, J. N., \& Levendusky, M. S. (2019). What Do we measure when we measure affective polarization? Public Opinion Quarterly, 83(1), 114-122.

Druckman, J. N., Peterson, E., \& Slothuus, R. (2013). How elite partisan polarization affects public opinion formation. American Political Science Review, 107(1), 57-79.

Feldman, S. (2003). Enforcing social conformity: A theory of authoritarianism. Political Psychology, 24(1), 41-74.

Feldman, S. (2020). Authoritarianism, threat, and intolerance. In E. Borgida, C. M. Federico, \& J. M. Miller (Eds.), At the forefront of political psychology: Essays in honor of John L. Sullivan (pp. 35-55). New York, NY: Routledge.

Feldman, S., \& Stenner, K. (1997). Perceived threat and authoritarianism. Political Psychology, 18(4), 741-770.

Garrett, R. K., Gvirsman, S. D., Johnson, B. K., Tsfati, Y., Neo, R., \& Dal, A. (2014). Implications of pro-and counterattitudinal information exposure for affective polarization. Human Communication Research, 40(3), 309-332.

Gidron, N., Adams, J., \& Horne, W. (2019). Toward a comparative research agenda on affective polarization in mass publics. APSA Comparative Politics Newsletter, 29, 30-36.

Gilbrant, J., \& Suvatne, S. S. (2019, May 5). Sylvi Listhaug ny nestleder i Frp [Sylvi Listhaug new Deputy Leader in Frp]. Dagbladet. Retrieved from https://www.dagbladet.no/nyheter/sylvi-listhaugny-nestleder-i-frp/71042706

Hampson, S. E., \& Goldberg, L. R. (2006). A first large cohort study of personality trait stability over the 40 years between elementary school and midlife. Journal of Personality and Social Psychology, 91, 763-779.

Hansen, K. M., \& Kosiara-Pedersen, K. (2017). How campaigns polarize the electorate: Political polarization as an effect of the minimal effect theory within a multi-party system. Party Politics, 23(3), 181-192.

Hetherington, M. J., \& Weiler, J. D. (2009). Authoritarianism and polarization in American politics. Cambridge: University Press.

Hetherington, M., \& Suhay, E. (2011). Authoritarianism, threat, and Americans' support for the war on terror. American Journal of Political Science, 55(3), 546-560.

Hug, S. (2019). Just say no to $p<x(\forall x \in(0,1]),{ }^{*}$ s and other evil things. Swiss Political Science Review, 25(3), 312-321.

Ivarsflaten, E. (2008). What unites right-wing populists in Western Europe? Re-Examining grievance mobilization in seven successful cases. Comparative Political Studies, 41(1), 3-23.

lyengar, S., \& Westwood, S. J. (2015). Fear and loathing across party lines: New evidence on group polarization. American Journal of Political Science, 59(3), 690-707.

Iyengar, S., Lelkes, Y., Levendusky, M., Malhotra, N., 
\& Westwood, S. J. (2019). The origins and consequences of affective polarization in the United States. Annual Review of Political Science, 22, 129-146.

Iyengar, S., Sood, G., \& Lelkes, Y. (2012). Affect, not ideology: A social identity perspective on polarization. Public Opinion Quarterly, 76(3), 405-431.

Jensen, S. (2020). Derfor går FrP ut av regjering [This is why FrP exits government]. Fremskrittspartiet. Retrieved from https://www.frp.no/aktuelt/2020/01/ derfor-g\%C3\%A5r-frp-ut-av-regjering

Johnsen, A. B., \& Hvidsten, I. (2013, September 17). Jens ber Siv beklage på norsk [Jens asks Siv apologize in Norwegian]. Verdens Gang. Retrieved from https://www.vg.no/nyheter/innenriks/i/KOgEe/jensber-siv-beklage-paa-norsk

Johnsen, N. (2019, April 19). Jonas Gahr Støre til VG: -Norge bør hente hjem barna til norske IS-kvinner [Jonas Gahr Støre to VG: -Norway should bring children of Norwegian IS-women home]. Verdens Gang. Retrieved from https://www.vg.no/nyheter/ utenriks/i/LA4rn1/jonas-gahr-stoere-til-vg-norgeboer-hente-hjem-barna-til-norske-is-kvinner

Jupskås, A. R. (2015). The persistence of populism. The Norwegian progress party 1973-2009 (PhD thesis). University of Oslo, Oslo.

Jupskås, A. R. (2016). The taming of the shrew: How the Progress Party (almost) became part of the mainstream. In T. Akkerman, S. L. De Lange, \& M. Rooduijn (Eds.), Radical right-wing populist parties in Western Europe (pp. 187-210). London and New York, NY: Routledge.

Knudsen, E. (2018). Affective polarization in multiparty systems? Comparing Norway and the United States through the inter-party marriage measure (Working Paper 2018, No. 4). Bergen: University of Bergen.

Lauka, A., McCoy, J., \& Firat, R. B. (2018). Mass partisan polarization: Measuring a relational concept. American Behavioral Scientist, 62(1), 107-126.

Lavine, H., Lodge, M., \& Freitas, K. (2005). Threat, authoritarianism, and selective exposure to information. Political Psychology, 26(2), 219-244.

Lavine, H., Lodge, M., Polichak, J., \& Taber, C. (2002). Explicating the black box through experimentation: Studies of authoritarianism and threat. Political Analysis, 10(4), 343-361.

Lelkes, Y., \& Westwood, S. J. (2017). The limits of partisan prejudice. The Journal of Politics, 79(2), 485-501.

Levendusky, M. (2013). Partisan media exposure and attitudes toward the opposition. Political Communication, 30(4), 565-581.

Levendusky, M., \& Malhotra, N. (2016). Does media coverage of partisan polarization affect political attitudes? Political Communication, 33(2), 283-301.

Lödén, H. (2014). Peace, love, depoliticisation and the domestic alien: National identity in the memorial messages collected after the terror attacks in Norway 22 July 2011. National Identities, 16(2), 157-176.

Merolla, J. L., \& Zechmeister, E. J. (2009). Terrorist threat, leadership, and the vote: Evidence from three experiments. Political Behavior, 31(4), 575.

Mudde, C. (2007). Populist radical right parties in Europe. Cambridge: Cambridge University Press.

Mudde, C., \& Rovira Kaltwasser, C. (2018). Studying populism in comparative perspective: Reflections on the contemporary and future research agenda. Comparative Political Studies, 51(13), 1667-1693.

Nesser, P. (2018). Islamist terrorism in Europe. Oxford University Press.

Ravndal, J. A. (2018). Explaining right-wing terrorism and violence in Western Europe: Grievances, opportunities and polarisation. European Journal of Political Research, 57(4), 845-866.

Skjervheim, $\varnothing$., Høgest $\varnothing \mathrm{l}$, A., Bjørnebekk, O., \& Eikrem, A. (2019). Norwegian citizen panel methodology report wave (15 Tech. Rep.). Bergen: Ideas 2 Evidence. Retrieved from https://nsd.no/data/individ/ publikasjoner/NSD2743/NCP\%20Documentation\% 20Report\%20Wave\%2015.pdf

Sniderman, P. M., Hagendoorn, L., \& Prior, M. (2004). Predisposing factors and situational triggers: Exclusionary reactions to immigrant minorities. American Political Science Review, 98(1), 35-49.

Sørsdahl, E. (2018, March 13). - Hun nører oppunder hatet som tok så mange liv 22. juli [-She kindles hatred that took so many lives on July 22]. TV2. Retrieved from https://www.tv2.no/a/9738250

Stenner, K. (2005). The authoritarian dynamic. Cambridge: Cambridge University Press.

Stenner, K., \& Haidt, J. (2018). Authoritarianism is not a momentary madness, but an eternal dynamic within liberal democracies. In C. R. Sunstein (Ed.), Can it happen here? Authoritarianism in America (pp. 175-220). New York, NY: Harper Collins.

Stoltenberg, J. (2011). Tale ved Statsminister Jens Stoltenberg i Oslo Domkirke [Address by Prime Minister Jens Stoltenberg in Oslo Cathedral]. Office of Prime Minister Home Page. Retrieved from https://www.regjeringen.no/no/dokumentarkiv/ stoltenberg-ii/smk/taler-og-artikler/2011/tale-vedstatsminister-jens-stoltenberg-/id651789

Svaar, P. (2018, March 14). Listhaug har slettet Facebookinnlegg [Listhaug has deleted Facebook post]. NRK. Retrieved from https://www.nrk.no/norge/listhaugsletter-omstridt-facebook-innlegg-1.13961460

Sylvi Listhaug forsvarer utspillet som felte henne [Sylvi Listhaug defends statement that felled her]. (2018, October 22). Aftenposten. Retrieved from https:// www.aftenposten.no/norge/politikk/i/OndW1w/ sylvi-listhaug-forsvarer-utspillet-som-felte-henne

Vasilopoulos, P., \& Lachat, R. (2018). Authoritarianism and political choice in France. Acta Politica, 53(4), 612-634.

Vasilopoulos, P., Marcus, G. E., \& Foucault, M. (2018). Emotional responses to the Charlie Hebdo attacks: Addressing the authoritarianism puzzle. Political Psychology, 39(3), 557-575. 
Wasserstein, R. L., \& Lazar, N. A. (2016). The ASA's statement on p-values: Context, process, and purpose. The American Statistician, 70(2), 129-133.

Wasserstein, R. L., Schirm, A. L., \& Lazar, N. A. (2019). Moving to a world beyond " $p<.05$." The American Statistician, 73(sup1), 1-19.

Weisskircher, M., \& Berntzen, L. E. (2019). Remaining on the streets: Anti-Islamic PEGIDA mobilization and its relationship to far-right party politics. In C. Manuela \& C. Ondřej (Eds.), Radical right 'movement parties' in Europe (pp. 114-130). London and New York, NY: Routledge.

Westwood, S. J., Iyengar, S., Walgrave, S., Leonisio, R., Miller, L., \& Strijbis, O. (2018). The tie that divides: Cross-national evidence of the primacy of partyism. European Journal of Political Research, 57(2), 333-354.

Wiggen, M. (2012). Rethinking anti-immigration rhetoric after the Oslo and Utøya terror attacks. New Political Science, 34(4), 585-604.

\section{About the Author}

Lars Erik Berntzen (PhD) is a Postdoctoral Fellow at the Department of Comparative Politics, University of Bergen and Affiliated Researcher at the Center for Research on Extremism, University of Oslo. Berntzen's work deals with the far-right, anti-Islamic mobilization, political violence, and issues of polarization. He is the author of Liberal Roots of Far Right Activism: The Anti-Islamic Movement in the 21st Century (Routledge, 2019). 